\title{
Peran Non Performing Financing terhadap Profitabilitas Bank Pembiayaan Rakyat \\ Syariah dengan Inflasi sebagai Variabel Moderasi
}

\author{
Muhammad Zulkarnain \\ Sekolah Tinggi Ilmu Ekonomi Haji Agus Salim Bukittinggi, Indonesia \\ mubammadzulkarnain1002@gmail.com \\ Heliyani \\ Sekolah Tinggi Ilmu Ekonomi Haji Agus Salim Bukittinggi, Indonesia \\ belivani isn@yahoo.co.id \\ Diterima : 21 Juni $2020 \quad$ Direvisi : 15 Juli 2020 \\ Diterbitkan : 17 Juli 2020

\begin{abstract}
The research aims to examine the role of Non-Performing Financing (NPF) on the profitability of financing in Sharia Banks with inflation as a moderation variable. The population of this research is Islamic Rural Banks in West Sumatra Indonesia, which was registered in the Financial Services Authority (OJK) in the 2015-2018 period. Samples of research were taken purposively as many as seven units of Islamic Rural Banks which were spread in West Sumatra Indonesia. The data analysis technique used is a regression method with panel data (pooled data) which is a combination of cross section and time series data using Software Eviews8. The results of the analysis showed that Non-Performing Financing (NPF) has a negative effect on profitability, which is proxied by $\mathrm{ROA}$. Furthermore, this research proves that the inflation does not moderate or weaken the influence of the NPF on the profitability of Islamic Rural Banks. This research contributes in expanding the direct relationship between NPF and profitability which in previous research was not elaborated further.
\end{abstract} \\ Abstract
}

Keywords: NPF, Inflation, Profitability, Islamic Rural Banks.

\begin{abstract}
Abstrak
Penelitian ini bertujuan untuk mengetahui peran Non Performing Financing (NPF) terhadap Profitabilitas Bank Pembiayaan Rakyat Syariah di Sumatera Barat dengan Inflasi sebagai variabel moderasi. Populasi penelitian ini adalah Bank Pembiayaan Rakyat Syariah (BPRS) yang terdaftar pada Otoritas Jasa Keuangan (OJK) pada periode tahun 2015-2018. Sampel penelitian diambil dengan cara purposive sampling, sehingga diperoleh sampel 7 BPRS yang ada di Sumatera Barat.Tehnik analisis data yang digunakan adalah metode regresi data panel (pooled data) yang merupakan gabungan dari data cross section dan data time series dengan menggunakan Software Eviews8. Hasil analisis menunjukkan Non Performing Financing (NPF) memiliki hubungan negatif dan signifikan terhadap Profitabilitas (ROA) BPRS di Sumatera Barat, Inflasi tidak terbukti memperlemah peran NPF terhadap Profitabilitas BPRS di Sumatera Barat pada periode tahun 2015-2018. Penelitian ini berkontribusi dalam memperluas hubungan langsung antara NPF dengan profitabilitas yang dalam riset terdahulu tidak di elaborasi lebih detail.
\end{abstract}

Kata Kunci: NPF, Inflasi, Profitabilitas, BPRS.

\section{Latar Belakang}

Bank Pembiayaan Rakyat Syariah (BPRS) sebagai salah satu Lembaga Keuangan Mikro formal yang ada di Indonesia,

Muhammad Zulkarnain dan Heliyani berkomitmen untuk memberikan jalur kemudahan dalam mendapatkan modal bagi pengusaha kecil dan mikro, serta masyarakat berpenghasilan rendah yang tidak terlayani oleh bank-bank komersial. Hal ini sejalan
Peran Non Performing Financing ... 
dengan Ledgerwood ${ }^{1}$ yang menyebutkan bahwa Lembaga Keuangan Mikro (microfinance) adalah sebagai Penyedia Layanan Keuangan bagi pengusaha kecil dan mikro serta berfungsi sebagai alat pembangunan bagi masyarakat pedesaan.

Sebagai Lembaga Keuangan Mikro, dalam operasionalnya BPRS dituntut untuk mencapai target kinerja keuangan yang sehat dan baik, terutama yang berhubungan dengan profitabilitas. Menurut Kasmir ${ }^{2}$ menyebutkan, bank yang sehat adalah bank yang profitabilitasnya terus meningkat. Karena, Profitabilitas digunakan untuk mengukur efektifitas manajemen berdasarkan hasil pengembalian dari pembiayaan dan investasi. Sehingga, penilaian kinerja keuangan pada BPRS sangat penting agar dapat memberikan kepercayaan kepada deposan dan investor guna menyimpan dananya.

Penilaian profitabilitas pada umumnya dilakukan dengan menggunakan rasio Return on Asset (ROA), karena Bank Indonesia lebih mementingkan penilaian besarnya profitabilitas (laba) berdasarkan rasio ROA. Rasio ROA dapat mengukur efektifitas bank di dalam menghasilkan keuntungan dengan memanfaatkan modal yang dimilikinya.

Perdebatan dalam upaya untuk mencapai tingkat profitabilitas yang maksimal selalu dikaitkan dengan adanya resiko pembiayaan bermasalah atau Non Performing Financing (NPF) pada suatu bank. Hasil penelitian tentang keterkaitan antara NPF dengan Profitabilitas (ROA) telah dilakukan Armereo $^{3}$ dan Almunawwarah dan Marliana ${ }^{4}$

1 Joanna Ledgerwood., Microfinance Handbook: An Institutional and Financial Perspective (The International Bank for Reconstruction and Development/The World Bank 1818 H Street, N.W. Washington, D.C. 20433, U.S.A., 1999).

${ }^{2}$ Kasmir, Bank Dan Lembaga Keuangan Lainnya (Jakarta: PT RajaGrafindo Persada, 2013).

${ }^{3}$ Crystha Armereo, 'Profitabilitas Bank Syariah Yang Terdaftar', Jurnal Ilmiah Ekonomi Global Masa Kini, 06.01 (2015), 48-56.

Muhammad Zulkarnain dan Heliyani yang menyatakan bahwa NPF berpengaruh negatif terhadap ROA, yang berarti bahwa semakin tinggi pembiayaan bermasalah (NPF) akan berdampak pada semakin rendahnya laba (ROA) bank. Sebaliknya, semakin rendah pembiayaan bermasalah (NPF) akan berdampak pada semakin tingginya laba (ROA) bank.

Sedangkan hasil berbeda ditunjukkan penelitian yang dilakukan oleh Rahmi dan Anggraini, ${ }^{5}$ Mulyati dan Khoiruddin, ${ }^{6}$ dan Husaeni ${ }^{7}$ yang menyatakan bahwa NPF berpengaruh positif terhadap ROA, yang berarti bahwa semakin tinggi pembiayaan bermasalah (NPF) akan berdampak pada peningkatan laba (ROA) bank. ${ }^{8}$ Sebaliknya, semakin rendah pembiayaan bermasalah (NPF) akan berdampak pada penurunan profitabilitas bank.

Adanya hasil penelitian yang tidak konsisten antara peran NPF terhadap profitabilitas bank tersebut, diduga ada pengaruh inflasi yang menyebabkannya. Karena inflasi adalah kenaikan harga-harga barang dan jasa secara terus-menerus dalam periode tertentu, atau dikatakan juga menurunnya nilai mata uang terhadap barang dan jasa. Sehingga mempengaruhi NPF terhadap profitabilitas BPRS.

4 Medina Almunawwaroh and Rina Marliana, "Pengaruh CAR, NPF dan FDR terhadap Profitabilitas Bank Syariah Di Indonesia," Amwaluna: Jurnal Ekonomi Dan Keuangan Syariah 2, no. 1 (2018): 1-17.

${ }^{5}$ Nurul Rahmi and Ratna Anggraini, 'Pengaruh CAR, BOPO, NPF, DAN CSR DISCLOSURE Terhadap Profitabilitas Perbankan Syariah', Jurnal Ilmiah Wahana Akuntansi, 8.2 (2013), 171-87.

${ }^{6}$ Moh. Khoiruddin Sri Muliawati, 'Faktor-Faktor Penentu Profitabilitas Bank Syariah Di Indonesia', Management Analysis Journal, 4.1 (2015), 39-49.

${ }^{7}$ Husaeni Ahmad, Uus, 'Analisis Pengaruh Dana Pihak Ketiga Dan Non Performing Financing Terhadap Return On Asset Pada BPRS Di Indonesia', Jurnal Ekonomi Syariah, 5.October (2017), 1-16.

${ }^{8}$ Hesi Eka Puteri, 'Predicting The Impact of Commercialization Factors On The Social Mission Of ISlamic Microfinance Institutions For Muslim Community', Islam Realitas, 6.1 (2020), 14-28. 
Hasil penelitian yang dilakukan oleh Sufian, ${ }^{9}$ Chowdhury dan Rasid, ${ }^{10}$ dan Islam \& Nishiyama ${ }^{11}$ yang menyatakan bahwa Inflasi memiliki pengaruh positif dan signifikan terhadap profitabilitas bank. Artinya, semakin tinggi inflasi akan berdampak pada peningkatan laba bank. Sebaliknya, semakin rendah inflasi akan berdampak pada penurunan laba bank. Sedangkan penelitian yang dilakukan oleh Dwijayanthy dan Naomi ${ }^{12}$ menyatakan bahwa Inflasi berpengaruh negatif terhadap profitabilitas bank. Inflasi yang tinggi menjadikan ketidaksetabilan makro yang menyebabkan meningkatnya resiko bank dan selanjutnya berdampak pada profitabilitas bank.

Berdasarkan uraian-uraian di atas, maka penelitian ini penting dilakukan, karena terdapat adanya hasil yang tidak konsisten tentang peran NPF terhadap profitabilitas (ROA) bank, seperti hasil-hasil penelitian yang telah disebutkan di atas. Tujuan kajian ini adalah untuk mengestimasi peran NPF sebagai variabel independen dan inflasi sebagai variabel moderasi peran NPF terhadap Profitabilitas BPRS di Sumatera Barat. Untuk itu, penulis menggunakan metode regresi data panel (pooled data) untuk menguji variabelvariabel tersebut.

\section{Literature Review}

9 Fadzlan Sufian, 'Factors Influencing Bank Profitability in a Developing Economy: Empirical Evidence from Malaysia', Global Business Review, 10.2 (2009).

10 Mohammad Ashraful Ferdous Chowdhury and Mohamed Eskandar, 'The Determinants of the Profitability of Islamic Banks: A Cross-Sectional Study from Asia and Africa', International Journal of Business and Globalisation (IJBG), 15.3 (2015).

11 Shin-Ichi and Md. Shahidul Islam Nishiyama, 'Using the GMM Estimator, This Paper Empirically Studies the Bank-Specific, Industry Specific and Macroeconomics Specific Determinants of Bank Profitability of 259 Commercial Banks in the South Asian Countries (Bangladesh, India, Nepal and Pakistan) for Th', Journal of Applied Finance \& Banking, 6.3 (2016).

12 Febrina Dwijayanthy, 'Analisis Pengaruh Inflasi , BI Rate, Dan Nilai Tukar Mata Uang Terhadap Profitabilitas Bank', 3.2 (2009), 87-98.

Muhammad Zulkarnain dan Heliyani

\section{Bank Pembiayaan Rakyat Syariah (BPRS)}

Dalam usaha untuk meningkatkan perekonomian masyarakat di wilayah pedesaan, BPRS hadir dengan fungsi utamanya sebagai lembaga keuangan yang didirikan untuk melayani Usaha Mikro dan Kecil (UMK) yang pengelolaannya harus berdasarkan prinsip syariah. Usaha yang dapat dilaksanakan oleh BPRS dalam fungsinya sebagai lembaga intermediary: ${ }^{13}$

1. Menghimpun dana dari masyarakat dalam bentuk simpanan, seperti deposito, tabungan, atau dalam bentuk lainnya.

2. Menyiapkan pembiayaan dan penempatan dana berdasarkan Prinsip Syari'ah, sesuai dengan ketentuan yang ditetapkan oleh Bank Indonesia.

3. Menletakkan dananya dalam bentuk Sertifikat Bank Indonesia (SBI), deposito berjangka, sertifikat deposito, dan atau tabungan pada pihak lain.

Masyarakat Indonesia yang pada awalnya hanya mengenal BPR yang merupakan kepanjangan dari Bank Perkreditan Rakyat yang dalam melaksanakan kegiatan usahanya berdasar pada prinsip bunga. Dalam perkembangan selanjutnya, masyarakat juga mengenal BPR Syariah yang dalam melaksanakan kegiatan usahanya berdasar pada prinsip bagi hasil.

\section{Profitabilitas}

Profitabilitas atau Return On Asset (ROA) merupakan rasio untuk menilai kemampuan perusahaan dalam mencari keuntungan. Penilaian kinerja keuangan perbankan dapat dinilai dari pendekatan analisis rasio keuangan yang juga memberikan ukuran tingkat efektivitas manajemen suatu perusahaan. ${ }^{14}$

${ }^{13}$ Hesi Eka Puteri, 'Kontribusi BPRS Merealisasi Financial Inclusion Dalam Penguatan Ekonomi Lokal: Evaluasi Empiris Dan Penguatan Strategi', Islam Realitas: Journal of Islamic \& Social Studies, 1.1 (2015), 19-34.

${ }^{14}$ Kasmir, Kewirausahaan (Jakarta: Rajawali Pers, 2014).

\section{Peran Non Performing Financing ...}


ROA (Return On Asset) adalah perbandingan antara pendapatan bersih (net income) dengan rata-rata aktiva (average assets). ROA merupakan rasio profitabilitas yang mengukur kemampuan perusahaan menghasilkan keuntungan pada tingkat penjualan, asset dan modal saham yang tertentu. ${ }^{15}$ Semakin besar rasio ROA (Return on Asset) pada perbankan, semakin besar pula tingkat laba yang diperoleh bank tersebut, dan semakin baik pula posisi perbankan tersebut dari sisi penggunaan asset. ${ }^{16}$

Tujuan penggunaan rasio ini bagi perusahaan maupun bagi pihak luar perusahaan adalah: $:^{17}$

1. Untuk menentukan laba yang diperoleh perusahaan dalam satu periode tertentu.

2. Untuk menentukan posisi laba perusahaan tahun sebelumnya dengan tahun sekarang.

3. Untuk menentukan perkembangan laba dari waktu ke waktu.

4. Untuk menentukan besarnya laba bersih sesudah pajak dengan modal sendiri.

5. Untuk menentukan produktifitas semua dana perusahaan yang digunakan, baik modal pinjaman maupun modal sendiri.

Untuk menilai tingkat kesehatan bank syariah berdasarkan besarnya Return On Asset (ROA), ${ }^{18}$ Bank Indonesia telah menentukan kriteria sebagai berikut: ${ }^{19}$

${ }^{15}$ Mamduh M. Hanafi dan Abdul Halim, Analisis Laporan Keuangan (Yogyakarta: UPP STIM YKPN, 2009).

16 Anne-lucie Lafourcade and others, 'Overview of the Outreach and Financial Performance of Microfinance Institutions in Africa', Microfinance Information EXchange; Washington; DC. Http://Www. Mixmarket. Org/Medialibrary/Mixmar, 2005; Hesi Eka Puteri, 'Social Performance of Rural Bank: Impact of Commercialization Factors', Jumal Dinamika Manajemen, $11.36 \quad$ (2020), 115-25 <https://doi.org/10.15294/jdm.v11i1.23091>;

Dwijayanthy.

17 Kasmir, Analisis Laporan Keuangan (Jakarta: Rajawali Pers, 2012).

${ }^{18}$ Hidayatul Arief, Iiz Izmuddin, and Hesi Eka Puteri, 'Pengaruh Financial Sustainability Terhadap Jangkauan BPR Syariah Di Propinsi Sumatera Barat', Muhammad Zulkarnain dan Heliyani
Tabel 1. Kriteria Penilaian Peringkat ROA

\begin{tabular}{|l|l|l|}
\hline Peringkat & \multicolumn{1}{|c|}{ Kriteria } & Keterangan \\
\hline \hline Peringkat 1 & ROA $>1,5 \%$ & Sangat sehat \\
\hline Peringkat 2 & $1,25 \%<\mathrm{ROA} \leq 1,5 \%$ & Sehat \\
\hline Peringkat 3 & $0,5 \%<\mathrm{ROA} \leq 1,25 \%$ & Cukup sehat \\
\hline Peringkat 4 & $0 \%<\mathrm{ROA} \leq 0,5 \%$ & Kurang sehat \\
\hline Peringkat 5 5 & ROA $\leq 0 \%$ & Tidak sehat \\
\hline
\end{tabular}

Sumber: Bank Indonesia, 2012.

Non Performing Financing (NPF)

NPF merupakan rasio keuangan yang menggambarkan resiko dalam pembiayaan yang dihadapi bank akibat pemberian pembiayaan dan investasi dana bank pada portofolio yang berbeda. Semakin kecil NPF, menyebabkan semakin kecilnya resiko pembiayaan yang ditanggung pihak bank. Jika bank memiliki rasio Non Performing Financing yang tinggi, ini menunjukkan bahwa bank tersebut tidak professional dalam mengelola pembiayaannya, sekaligus memberikan indikasi bahwa tingkat resiko atau pemberian pembiayaan pada bank tersebut cukup tinggi searah dengan tingginya NPF yang dialami bank. $^{20}$

Resiko pembiayaan ini dapat terjadi akibat kegagalan atau ketidakmampuan nasabah dalam mengembalikan jumlah pinjaman yang diterima dari bank beserta bagi hasilnya sesuai dengan jangka waktu yang telah dijadwalkan. ${ }^{21}$

Untuk menilai tingkat kesehatan bank syariah berdasarkan besarnya Non Performing

Ekonomika Syariah: Journal of Economic Studies, 3.2 (2019), 32-46.

${ }^{19}$ Ramlan Ginting Dudy Iskandar and Gantiah Wuryandani Anggayasti Hayu Anindita Tresna Kholilah, Kodifikasi Peraturan Bank Indonesia Kelembagaan Penilaian Tingkat Kesehatan Bank Umum (Jakarta: Bank Indonesia, 2013).

20 Slamet Riyadi, Banking Assets And Liability Management, Edisi Ke-3 (Jakarta: Lembaga Penerbit Fakultas Ekonomi Universitas Indonesia, 2006).

${ }^{21}$ Mudrajad Kuncoro, Manajemen Perbankan Teori Dan Aplikasi (Yogyakarta: BPFE, 2002). 
Financing (NPF), Bank Indonesia telah menentukan kriteria sebagai berikut: ${ }^{22}$

Tabel 2. Kriteria Penilaian Peringkat NPF

\begin{tabular}{|l|l|l|}
\hline Peringkat & \multicolumn{1}{|c|}{ Kriteria } & Keterangan \\
\hline \hline Peringkat 1 & $\mathrm{NPF}<2 \%$ & Sangat sehat \\
\hline Peringkat 2 & $2 \% \leq \mathrm{NPF}<5 \%$ & Sehat \\
\hline Peringkat 3 & $5 \% \leq \mathrm{NPF}<8 \%$ & Cukup sehat \\
\hline Peringkat 4 & $8 \% \leq \mathrm{NPF}<12 \%$ & Kurang sehat \\
\hline Peringkat 5 & $\mathrm{NPF} \geq 12 \%$ & Tidak sehat \\
\hline
\end{tabular}

Sumber : Bank Indonesia, 2012.

\section{Inflasi}

Inflasi menandakan adanya suatu fenomena moneter, karena terjadinya penurunan nilai unit perhitungan moneter terhadap suatu komoditi. Inflasi merupakan suatu kecenderungan adanya peningkatan harga-harga barang dan jasa secara umum dan terus-menerus. ${ }^{23}$ Berdasarkan definisi tersebut, ada dua pengertian khusus yang menjadi perhatian dalam inflasi, yaitu pertama adalah kenaikan harga secara umum dan kedua adalah terus-menerus.

Secara umum, penyebab terjadinya inflasi menurut ekonomi Islam seperti yang disebutkan oleh al-Maqrizi adalah: ${ }^{24}$

1. Inflasi Alami (Natural Inflation), yaitu inflasi yang terjadi karena sebab-sebab alamiah. Manusia tidak punya kuasa untuk mencegahnya. Inflasi ini disebabkan oleh turunnya penawaran agregatif atau naiknya

22 Ramlan Ginting Chandra Murniadi, Dudy Iskandar, Gantiah Wuryandani, Zulkarnain Sitompul, Siti Astiyah, Wahyu Yuwana Hidayat, Komala Dewi, Wirza Ayu Novriana, Chiristin Natalia Hutabarat, Riska Rosdiana, Kodifikasi Peraturan Bank Indonesia Kelembagaan Penilaian Tingkat Kesehatan Bank Umum (Jakarta: PRES Bank Indonesia, 2012).

23 Suseno and Siti Astiyah, Seri Kebanksentralan No. 22 - Inflasi, Bank Indonesia (Jakarta: PPSK Bank Indonesia, 2015).

${ }^{24}$ Rozalinda, Ekonomi Islam Teori Dan Aplikasinya Pada Aktifitas Ekonomi (Jakarta: PT RajaGrafindo Persada, 2015). permintaan agregatif. Pada waktu bencana alam terjadi, berbagai bahan makanan dan hasil bumi lainnya mengalami gagal panen, sehingga persediaan barang-barang kebutuhan tersebut mengalami penurunan dan terjadi kelangkaan. Di pihak lain, karena barang-barang itu sangat diperlukan dalam kehidupan, permintaan terhadap berbagai barang mengalami peningkatan. Harga-harga barang yang melambung tinggi jauh melebihi daya beli masyarakat. Sehingga mengakibatkan aktifitas perekonomian mengalami kemacetan, bahkan dapat berhenti sama sekali, yang pada akhirnya menimbulkan bencana kelaparan, wabah penyakit, kematian. Keadaan ini memaksa masyarakat untuk mendesak pemerintah supaya memperhatikan mereka. Untuk menanggulangi bencana ini, pemerintah mengeluarkan dana besar yang mengakibatkan perbendaharaan negara menjadi berkurang secara drastis atau defisit anggaran.

Inflasi Alami (Natural Inflation) dapat dibedakan berdasarkan penyebabnya menjadi dua, yaitu:

a. Uang yang masuk dari luar negeri terlalu banyak karena ekspor meningkat sedangkan impor menurun sehingga net ekspor nilainya sangat besar yang mengakibatkan naiknya permintaan agregatif. Situasi ini, pernah terjadi pada masa Umar ibn Khatab, pada masa itu ekportir yang menjual barangnya ke luar negeri membeli barang-barang dari luar negeri (impor) lebih sedikit jumlahnya dari barang yang mereka jual (positive net export). Adanya positive net export ini, akan menjadikan keuntungan yang berupa kelebihan uang yang akan dibawa ke Madinah sehingga pendapatan dan daya beli masyarakat meningkat. Naiknya permintaan keseluruhan barang dan jasa Peran Non Performing Financing ... 
(agregat), akan menyebabkan naiknya tingkat harga secara keseluruhan. Untuk mengatasi situasi ini, Umar bin Khattab, mencegah penduduk Madinah untuk membeli barang-barang atau komoditi selama 2 hari berturut-turut, akibatnya terjadi penurunan permintaan agregatif, dan tingkat harga kembali normal.

b. Turunnya tingkat produksi karena terjadinya kekurangan bahan makanan (paceklik), perang ataupun sangsi ekonomi. Masa kekurangan bahan makanan (paceklik) ini pernah terjadi pada masa Umar bin Khattab yang menyebabkan kelangkaan gandum yang berdampak pada naiknya tingkat hargaharga.

2. Inflasi karena kesalahan manusia (buman error inflation), yaitu inflasi yang terjadi karena :

a. Korupsi dan buruknya administrasi (Corruption and bad administration) Pengangkatan para pejabat berdasarkan suap, nepotisme, dan bukan karena kapabilitas akan menempatkan orangorang pada berbagai jabatan penting dan terhormat yang tidak mempunyai kredibilitas. Mereka yang mempunyai mental seperti ini, rela menggadaikan seluruh harta milik untuk meraih jabatan, kondisi ini juga akan berpengaruh ketika mereka berkuasa. Para pejabat tersebut akan menyalahgunakan kekuasaannya untuk memperoleh kepentingan pribadi, baik untuk mencukupi keperluan finasial pribadi maupun untuk keluarga atau demi kemewahan hidup. Hal ini mengakibatkan akan terjadinya penurunan tajam terhadap penerimaan dan pendapatan Negara.

Korupsi akan mempengaruhi tingkat harga, karena produsen akan menaikkan harga jual barangnya untuk menutupi biaya-biaya siluman yang telah mereka keluarkan. Dimasukkannya biaya siluman dalam biaya produksi, akan menaikkan total biaya produksi. Hal ini menjadi tidak menunjukkan nilai sumber daya sebenarnya yang digunakan dalam proses produksi. Harga yang timbul, dipengaruhi oleh komponen yang seharusnya tidak ada sehingga lebih lanjut mengakibatkan sekonomi biaya tinggi (bigh cost economy) pada akhirnya akan terjadi inefisiensi alokasi sumber daya yang tentu akan merugikan masyarakat secara keseluruhan.

Keadaan inilah yang sebenarnya menyebabkan perkonomian Indoensia semakin terpuruk. Penyakit korupsi dan buruknya administrasi ini menyebar mulai dari pejabat tinggi sebagai pemegang otoritas tertinggi sampai ke tingkat lurah/desa. Sehingga pada setiap berurusan dengan administrasi dan birokrasi selalu ada uang siluman. Keadaan inipun sampai ketingkat pedagang kecil, uang takut/keamanan yang dipungut preman jelas merugikan masyarakat.

b. Excessive tax (pajak yang tinggi). Dampak dari banyaknya pejabat pemerintahan yang bermental korup, pengeluaran negara mengalami peningkatan yang sangat drastis, sebagai kompensasi mereka menerapkan sistem perpajakan tinggi dan menerapkan berbagai jenis pajak. Akibat dari penerapan pajak yang berlebihan, hampir sama dengan dengan efek yang ditimbulkan oleh korupsi dan buruknya administrasi, yaitu efisensi loss atau dead weigh loss. Konsekuensinya biaya produksi meningkat, dan akan berimbas pada kenaikan harga barang produksi.

c. Excessive sieignore (percetakan uang berlebihan). Ketika terjadi kekurangan anggaran, baik sebagai akibat dari kemacetan ekonomi, maupun perilaku Peran Non Performing Financing ... 
buruk para pejabat yang menghabiskan uang negara, pemerintah melakukan percetakan uang fulus secara besarbesaran. Menurut Maqrizi, pencetakan uang yang berlebihan, akan menyebabkan naiknya tingkat harga, menurunnya nilai mata uang secara drastis, akibatnya uang tidak lagi bernilai. Al-Maqrizi menyebutkan bahwa kenaikan harga komoditi adalah kenaikan dalam bentuk jumlah uang fulus, sedangkan jika diukur dengan emas (dinar), harga-harga komoditas itu jarang sekali mengalami kenaikan. Sebaiknya, uang dicetak hanya pada tingkat minimal yang dibutuhkan untuk bertransaksi dan dalam pecahan yang mempunyai nilai nominal yang kecil.

Umumnya, pada negara-negara industri, inflasi berasal dari salah satu atau gabungan dari dua masalah berikut:

1. Tingkat pengeluaran agregat (keseluruhan barang dan jasa) yang melebihi kemampuan perusahaan untuk menghasilkan barangbarang dan jasa. Keinginan untuk memperoleh barang yang dibutuhkan akan mendorong para konsumen meminta barang itu pada harga yang lebih tinggi. Sebaliknya, para pengusaha akan menyimpan barangnya dan hanya akan menjual kepada pembeli-pembeli yang bersedia membayar pada harga yang lebih tinggi. Kedua kecenderungan ini akan menyebabkan kenaikan harga-harga.

2. Para pekerja di berbagai aktifitas perekonomian menuntut adanya kenaikan upah. Bila para pengusaha mengalami kesulitan dalam mendapatkan tambahan tenaga kerja untuk meningkatkan produksi, maka pekerja-pekerja yang ada akan terdorong untuk meminta kenaikan upah. Bila kenaikan upah berlaku secara menyeluruh, maka akan terjadi kenaikan biaya produksi dari berbagai barang dan jasa yang dihasilkan dalam perekonomian. Kenaikan biaya produksi tersebut akan mendorong perusahaan menaikkan hargaharga barang mereka. Di dalam perekonomian yang sudah maju, masalah inflasi sangat erat kaitannya dengan tingkat penggunaan tenaga kerja.

Di samping itu inflasi dapat pula berlaku sebagai akibat dari:

1. Kenaikan harga barang impor,

2. Peningkatan penawaran uang yang berlebihan tanpa diikuti oleh peningkatan produksi dan penawaran barang,

3. Kekacauan politik dan ekonomi, disebabkan oleh pemerintahan yang kurang bertanggungjawab.

Selain adanya peningkatan uang beredar, maka peningkatan permintaan juga disebabkan oleh expected inflation. Bila masyarakat meyakini bahwa inflasi pada tahun ini akan tinggi, maka masyarakat cenderung membelanjakan uangnya saat ini untuk membeli dan menyimpan barang, terutama barang-barang yang bisa melindungi kekayaan dari inflasi misalnya emas dan properti. Akibatnya, inflasi jadi melambung.

Inflasi juga bisa terjadi karena masyarakat ingin hidup di luar batas kemampuannya. Keterbatasan kekayaan yang dimiliki menyebabkan masyarakat menggunakan kartu kredit untuk melakukan belanja. Penggunaan kartu kredit untuk konsumsi merupakan upaya belanja dengan menggunakan kekayaan yang diharapkan akan diterima di masa datang. Hal ini menyebabkan bertambahnya uang yang beredar yang melebihi pendapatan yang bersangkutan yang mendorong terjadinya inflasi.

Berdasarkan tingkat keparahan suatu inflasi, maka inflasi dibagi menjadi empat jenis, yaitu: $:^{25}$
25 Boediono, Ekonomi Makero (Yogyakarta: BPFE, 2011). 
1. Inflasi ringan, terjadi apabila tingkat inflasi kurang dari $10 \%$ per tahun.

2. Inflasi sedang, terjadi apabila tingkat inflasi antara $10 \%$ sampai $30 \%$ per tahun.

3. Inflasi berat, terjadi apabila tingkat inflasi antara $30 \%$ sampai $100 \%$ per tahun.

4. Hiper inflasi, disebut juga inflasi yang tidak terkendali, tingkat inflasi dalam setahun lebih dari $100 \%$, dan menyebabkan hargaharga barang terus berubah dan meningkat, sehingga orang tidak dapat menahan uang lebih lama karena disebabkan oleh nilai mata uang yang terus menurun.

Kebalikan dari inflasi adalah deflasi, yaitu menurunnya harga secara terus-menerus. Hal ini mengakibatkan kemampuan beli dari masyarakat bertambah besar, sehingga pada periode awal, barang-barang menjadi langka. Akan tetapi, pada periode berikutnya jumlah barang akan semakin banyak karena semakin berkurangnya daya beli masyarakat. ${ }^{26}$

\section{Metode Penelitian}

Data. Populasi dalam penelitian ini adalah semua BPRS yang ada di Provinsi Sumatera Barat pada tahun 2018 yang berjumlah sebanyak 7 BPRS. Sampel penelitian adalah semua BPRS yang merupakan populasi dari penelitian ini yang dipilih dengan cara purposive sampling. Data penelitian adalah data panel per triwulanan dari tahun 2015 sampai dengan 2018 yang diperoleh dari situs www.ojk.go.id yang merupakan website Otoritas Jasa Keuangan dan situs www.bi.go.id yang merupakan website Bank Indonesia.

Variabel Penelitian. Variabel penelitian terdiri dari tiga variabel, yaitu pertama Profitabilitas yang diwujudkan dalam bentuk Return On Assets (ROA) merupakan variabel dependen yang dipengaruhi oleh variabel lain, kedua Non Performing Ratio (NPF) merupakan variabel independen yang mempengaruhi

26 Iskandar Putong, Economics Pengantar Mikro Dan Makro (Jakarta: Mitra Wacana Media, 2009). Muhammad Zulkarnain dan Heliyani variabel dependen, dan ketiga Inflasi sebagai variabel moderasi yang merupakan variabel independen yang akan memperkuat atau memperlemah hubungan antara variabel NPF terhadap variabel ROA.

Metode Analisis. Penelitian ini akan mengestimasi peran NPF terhadap Profitabilitas BPRS dan Inflasi sebagai variabel moderasi peran NPF terhadap Profitabilitas BPRS di Sumatera Barat dengan menggunakan metode regresi data panel (pooled data) yang merupakan gabungan dari data cross section dan data time series, dengan software Eviews 8.

Untuk mengestimasi variabel-variabel tersebut digunakan model persamaan regresi sebagai berikut:

$$
Y=a+b 1 X 1+b 2 X 2+b 3 X 1 X 2+e
$$

Keterangan :

$$
\begin{array}{ll}
Y & =\text { Profitabilitas (ROA) } \\
a & =\text { Konstanta } \\
b & =\text { Koefisien Regresi } \\
X 1 & =\text { NPF } \\
X 2 & =\text { Inflasi } \\
X 1 X 2 & =\text { Moderasi NPF dengan Profitabilitas } \\
e & =\text { Residual }
\end{array}
$$

Agus Widarjono ${ }^{27}$ menyebutkan bahwa dalam metode estimasi model regresi data panel, menggunakan tiga model, pertama Common Effect Model (CEM) merupakan suatu model estimasi regresi data panel yang paling sederhana dengan asumsi intersep dan koefisien regresi (slope) yang tetap (konstan) antar waktu dan cross section. ${ }^{28}$ Kedua Fixed Effect Model (FEM) merupakan cara mengestimasi data panel dengan menggunakan variabel dummy untuk menangkap adanya perbedaan intersep

27 Agus Widarjono, Ekonometrika Dan Aplikasinya, Edisi Ke-3 (Yogyakarta: Ekonisia, 2009).

28 Uma Sekaran and Roger Bougie, Research Methods for Business: A Skill Building Approach (John Wiley \& Sons, 2016); Joseph F Hair and others, Multivariate Data Analysis (Englewood Cliffs, NJ: Prentice Hall). 
yang didasarkan adanya perbedaan antar perusahaan, namun intersepnya konstan antar waktu. Dan ketiga Random Effect Model (REM) merupakan metode estimasi model regresi data panel dengan asumsi bahwa koefisien regresi (slope) konstan dan intersep berbeda antar waktu dan antar individu (random effect).

Dari tiga model yang telah diestimasi tersebut, dipilih model yang paling tepat untuk tujuan penelitian ini dengan melakukan tiga uji, pertama Chow Test (F Test) yaitu untuk memilih model mana yang terbaik antara CEM dan FEM, kedua Hausman Test yaitu untuk memilih model mana yang terbaik antara FEM dan REM, dan ketiga Lagrange Multiplier Test yaitu untuk memilih model mana yang terbaik antara CEM dan REM.

\section{Hasil dan Pembahasan}

Hasil pemilihan model estimasi data panel dengan Uji Chow dan Uji Hausman, maka model estimasi yang terpilih pada penelitian ini adalah Random Effect Model (REM), dengan hasil sebagai berikut:

\section{Tabel 3. Random Effect Model}

\begin{tabular}{|c|c|c|c|c|}
\hline \multicolumn{5}{|c|}{ Dependent Variable: $\mathrm{Y}$} \\
\hline \multicolumn{5}{|c|}{ Method: Panel EGLS (Cross-section random effects) } \\
\hline \multicolumn{5}{|c|}{ Date: 09/14/19 Time: 09:11 } \\
\hline \multicolumn{5}{|c|}{ Sample: 2015Q1 2018Q4 } \\
\hline \multicolumn{5}{|c|}{ Periods included: 16} \\
\hline \multicolumn{5}{|c|}{ Cross-sections included: 7} \\
\hline \multicolumn{5}{|c|}{ Total panel (balanced) observations: 112} \\
\hline \multicolumn{5}{|c|}{ Swamy and Arora estimator of component variances } \\
\hline Variable & Coefficien & Std. Error & t-Statistic & Prob. \\
\hline $\mathrm{a}$ & 2.142822 & 0.467346 & 4.585083 & 0.0000 \\
\hline $\mathrm{X} 1$ & -0.054559 & 0.021195 & -2.574113 & 0.0114 \\
\hline $\mathrm{X} 2$ & 0.068733 & 0.066576 & 1.032410 & 0.3042 \\
\hline $\mathrm{X} 1 \mathrm{X} 2$ & -0.006071 & 0.003220 & -1.885362 & 0.0621 \\
\hline \multicolumn{5}{|c|}{ Effects Specification } \\
\hline & & & S.D. & Rho \\
\hline \multicolumn{3}{|c|}{ Cross-section random } & 0.804347 & 0.5778 \\
\hline \multicolumn{3}{|c|}{ Idiosyncratic random } & 0.687598 & 0.4222 \\
\hline \multicolumn{5}{|c|}{ Weighted Statistics } \\
\hline R-squared & \multicolumn{3}{|c|}{\begin{tabular}{|c|c|c|c|}
0.375512 & Mean dependent var
\end{tabular}} & 0.265198 \\
\hline $\begin{array}{l}\text { Adjusted R- } \\
\text { squared }\end{array}$ & \multicolumn{3}{|c|}{0.358166 S.D. dependent var } & 0.8503 \\
\hline S.E. of regression & \multicolumn{3}{|c|}{0.681275 Sum squared resid } & 50.12659 \\
\hline F-statistic & \multicolumn{3}{|c|}{ 21.64727 Durbin-Watson stat } & 1.681800 \\
\hline
\end{tabular}

Muhammad Zulkarnain dan Heliyani

\begin{tabular}{|l|l|l|l|}
\hline Prob(F-statistic) & 0.000000 & \\
\hline \multicolumn{3}{|c|}{ Unweighted Statistics } \\
\hline R-squared & 0.582539 & Mean dependent var & 1.268929 \\
\hline Sum squared resid & 91.72915 & Durbin-Watson stat & 0.923071 \\
\hline
\end{tabular}

Sumber : Hasil olah data primer, 2018

Sehingga persamaan regresinya menjadi :

$$
\mathbf{Y}=2,1428-0,0546 \mathbf{X}_{1}+0,0687 \mathbf{X}_{2}-0,0061 \mathbf{X}_{1} \mathbf{X}_{\mathbf{2}}+\mathrm{e}
$$$$
(\text { Sign. }=0,0114)(\text { Sign. }=0,3042)(\text { Sign. }=0,0621)
$$

Dari persamaan regresi tersebut, dapat diketahui bahwa nilai konstanta (a) adalah sebesar 2,1428 yang berarti tanpa adanya variabel NPF $\left(\mathbf{X}_{1}\right)$, dan Inflasi $\left(\mathbf{X}_{2}\right)$ maka nilai dari ROA (Y) adalah tetap, yaitu bernilai 2,1428. Koefisien regresi NPF $\left(\mathbf{X}_{1}\right)$ sebesar 0,0546 yang berarti jika tingkat NPF meningkat sebesar 1 satuan, maka akan menyebabkan penurunan ROA sebesar 0,0546 dengan asumsi variabel lainnya dianggap tetap.

Koefisien regresi Inflasi $\left(\mathbf{X}_{2}\right)$ sebesar 0,0687 yang berarti jika tingkat Inflasi meningkat sebesar 1 satuan, maka akan menyebabkan kenaikan ROA sebesar 0,0687 dengan asumsi variabel lainnya dianggap tetap demikian juga sebaliknya.

Sedangkan koefisien regresi $\mathbf{X}_{1} \mathbf{X}_{2}$ yang merupakan variabel Inflasi sebagai pemoderasi peran NPF terhadap ROA bernilai - 0,0061 (negatif) dengan signifikansi sebesar 0,0621 yang berarti bahwa variabel Inflasi memperlemah peran NPF terhadap profitabilitas dan tidak signifikan, karena nilai signifikansinya lebih besar dari 0,05 (0,0621 > $0,05)$.

\section{Koefisien determinasi}

Nilai koefisien determinasi $\left(\mathrm{R}^{2}\right)$ yang ditunjukkan oleh nilai Adjusted R-squared adalah sebesar 0,358166 (35,82\%). Artinya secara simultan besarnya pengaruh variabel NPF (Non Performing Financing) dan Inflasi terhadap variabel ROA adalah sebesar 35,82 \%, sedangkan sisanya sebesar $64,18 \%$ dipengaruhi oleh variabel lain yang tidak masuk dalam penelitian ini. 


\section{Peran NPF terbadap Profitabilitas}

Hasil penelitian tentang peran NPF terhadap profitabilitas BPRS ini, dilakukan dengan pendekatan Random Effect Model (REM). Variabel Non Performing Financing (NPF) memiliki nilai koefisien negatif sebesar 0,0546 dan nilai signifikansinya (Prob.) adalah 0,0114 (Signifikansi < 0,05). Artinya, Non Performing Financing (NPF) memiliki hubungan negatif dan signifikan terhadap profitabilitas (ROA) BPRS di Sumatera Barat pada periode tahun 2015-2018. Hasil ini sejalan dengan penelitian yang dilakukan oleh Almunawwarah dan Marliana ${ }^{29}$ yang menyatakan bahwa Non Performing Financing (NPF) berpengaruh negatif dan signifikan terhadap profitabilitas (ROA).

Hasil ini menunjukkan, semakin tinggi pembiayaan murabahah, mudharabah, dan musyarakah yang bermasalah (NPF) akan berdampak pada semakin rendahnya laba (ROA) Bank Pembiayaan Rakyat Syariah (BPRS) di Sumatera Barat. Sebaliknya, pembiayaan yang disalurkan BPRS, berpotensi menimbulkan pembiayaan murabahah, mudharabah, dan musyarakah yang bermasalah. Pembiayaan bermasalah ini dapat dilihat dari rasio Non Performing Financing (NPF). Sehingga apabila pembiayaan murabahah, mudharabah, dan musyarakah yang bermasalah semakin kecil, maka akan meningkatkan laba yang diperoleh Bank Pembiayaan Rakyat Syariah (BPRS) dan akan meningkatkan kepercayaan masyarakat untuk menyimpan uangnya di BPRS.

Inflasi sebagai Variabel Moderasi Peran NPF terbadap Profitabilitas

Inflasi sebagai variabel moderasi peran Non Performing Financing (NPF) terhadap Profitabilitas BPRS di Sumatera Barat pada periode tahun 2015-2018, digambarkan pada koefisien dari $\mathrm{X}_{1} \mathrm{X}_{2} \quad$ (NPF_Inflasi) yang nilainya negatif 0,006 dengan signifikansi

${ }^{29}$ Almunawwaroh and Marliana. Muhammad Zulkarnain dan Heliyani sebesar 0,0621 $(0,0621>0,05)$. Artinya, Inflasi memperlemah peran Non Performing Financing (NPF) terhadap Profitabilitas (ROA) BPRS di Sumatera Barat pada periode tahun 2015-2018, sehingga adanya inflasi tidak menguntungkan bagi BPRS di Sumatera Barat.

Hasil ini juga menunjukkan bahwa Non Performing Financing (NPF) yang merupakan rasio perbandingan antara jumlah pembiayaan yang bermasalah dengan jumlah pembiayaan yang disalurkan BPRS dan digunakan untuk mengukur kemampuan BPRS dalam mengukur resiko kegagalan pengembalian pembiayaan oleh debitur, mempunyai pengaruh nagatif terhadap terhadap profitabilitas BPRS dengan koefisien regresi sebesar -0,0546. Hal ini berarti bahwa semakin besar rasio NPF (pembiayaan bermasalah) akan mengakibatkan semakin kecil laba yang akan diperoleh BPRS. Resiko pembiayaan murabahah, mudharabah, dan musyarakah yang bermasalah atau kesulitan pengembalian pembiayaan oleh debitur dengan nilai yang besar dapat mengakibatkan terganggunya kinerja BPRS Besarnya pembiayaan murabahah, mudharabah, dan musyarakah yang bermasalah ini akan menyebabkan munculnya pencadangan dana yang lebih besar, karena besarnya NPF (pembiayaan bermasalah) mengakibatkan terhambatnya penyaluran pembiayaan BPRS, sehingga berdampak pada profitabilitas bank.

\section{Kesimpulan}

Non Performing Financing (NPF) memiliki hubungan negatif dan signifikan terhadap Profitabilitas (ROA) BPRS di Sumatera Barat pada periode tahun 2015-2018. Sedangkan variabel Inflasi tidak terbukti memperlemah pengaruh Non Performing Financing (NPF) terhadap Profitabilitas (ROA) BPRS di Sumatera Barat pada periode tahun 2015-2018. Temuan penelitian ini sudah memperkaya kajian-kajian serupa yang sudah membuktikan pengaruh NPF terhadap profitabilitas, dengan 
menguji inflasi dalam hubungan keterkaitan kedua variabel ini. Temuan ini dapat menjadi pertimbangan bagi Bank Pembiayaan Rakyat Syariah dalam pengambilan keputusan, terutama dalam menganalisis dampak makro ekonomi terhadap performa BPRS.

\section{Daftar Pustaka}

Ahmad, Uus, Husaeni, 'Analisis Pengaruh Dana Pihak Ketiga Dan Non Performing Financing Terhadap Return On Asset Pada BPRS Di Indonesia', Jurnal Ekonomi Syariah, 5 (2017), 1-16

Almunawwaroh, Medina, and Rina Marliana, 'Pengaruh Car,Npf Dan Fdr Terhadap Profitabilitas Bank Syariah Di Indonesia', Amwaluna: Jurnal Ekonomi Dan Kenangan Syariah, 2 (2018), 1-17

Arief, Hidayatul, Iiz Izmuddin, and Hesi Eka Puteri, 'Pengaruh Financial Sustainability Terhadap Jangkauan BPR Syariah Di Propinsi Sumatera Barat', Ekonomika Syariab: Journal of Economic Studies, 3 (2019), 32-46

Armereo, Crystha, 'Profitabilitas Bank Syariah Yang Terdaftar', Jurnal Ilmiah Ekonomi Global Masa Kini, 06 (2015), 48-56

Boediono, Ekonomi Makro (Yogyakarta: BPFE, 2011)

Chandra Murniadi, Dudy Iskandar, Gantiah Wuryandani, Zulkarnain Sitompul, Siti Astiyah, Wahyu Yuwana Hidayat, Komala Dewi, Wirza Ayu Novriana, Chiristin Natalia Hutabarat, Riska Rosdiana, Ramlan Ginting, Kodifikasi Peraturan Bank Indonesia Kelembagaan Penilaian Tingkat Kesehatan Bank. Umum (Jakarta: PRES Bank Indonesia, 2012)

Dwijayanthy, Febrina, 'Analisis Pengaruh Inflasi, BI Rate, Dan Nilai Tukar Mata Uang Terhadap Profitabilitas Bank', 3 (2009), 87-98

Eskandar, Mohammad Ashraful Ferdous Chowdhury and Mohamed, 'The Determinants of the Profitability of Islamic Banks: A Cross-Sectional Study from Asia and Africa', International Journal of Business and Globalisation (IJBG), 15 (2015)

Hair, Joseph F, William C Black, Barry J Babin, and and Rolph E. Anderson, Multivariate Data Analysis (Englewood Cliffs, NJ: Prentice Hall)

Halim, Mamduh M. Hanafi dan Abdul, Analisis Laporan Kenangan (Yogyakarta: UPP STIM YKPN, 2009)

Kasmir, Analisis Laporan Kenangan (Jakarta: Rajawali Pers, 2012)

__, Bank Dan Lembaga Keuangan Lainnya (Jakarta: PT RajaGrafindo Persada, 2013)

—, Kewirausahaan (Jakarta: Rajawali Pers, 2014)

Kuncoro, Mudrajad, Manajemen Perbankan Teori Dan Aplikasi (Yogyakarta: BPFE, 2002)

Lafourcade, Anne-lucie, Jennifer Isern, Patricia Mwangi, and Matthew Brown, 'Overview of the Outreach and Financial Performance of Microfinance Institutions in Africa', Microfinance Information EXchange; Washington; DC. Http://Www. Mixmarket. Org/Medialibrary/Mixmar, 2005

Ledgerwood., Joanna, Microfinance Handbook: An Institutional and Financial Perspective (The International Bank for Reconstruction and Development/The World Bank 1818 H Street, N.W. Washington, D.C. 20433, U.S.A., 1999)

Nishiyama, Shin-Ichi and Md. Shahidul Islam, 'Using the GMM Estimator, This Paper Empirically Studies the Bank-Specific, Industry Specific and Macroeconomics Specific Determinants of Bank Profitability of 259 Commercial Banks in the South Asian Countries (Bangladesh, India, Nepal and Pakistan) for Th', Journal of Applied Finance \& Banking, 6 (2016)

Puteri, Hesi Eka, 'Kontribusi BPRS Merealisasi Financial Inclusion Dalam Penguatan Ekonomi Lokal: Evaluasi Empiris Dan Penguatan Strategi', Islam 
Realitas: Journal of Islamic \& Social Studies, 1 (2015), 19-34

- 'Predicting The Impact of Commercialization Factors On The Social Mission Of ISlamic Microfinance Institutions For Muslim Community', Islam Realitas, 6 (2020), 14-28

, 'Social Performance of Rural Bank: Impact of Commercialization Factors', Jurnal Dinamika Manajemen, 11 (2020), 115-25

$<$ https://doi.org/10.15294/jdm.v11i1.23 $091>$

Putong, Iskandar, Economics Pengantar Mikro Dan Makro (Jakarta: Mitra Wacana Media, 2009)

Rahmi, Nurul, and Ratna Anggraini, 'Pengaruh CAR, BOPO, NPF, DAN CSR DISCLOSURE Terhadap Profitabilitas Perbankan Syariah', Jurnal Ilmiah Wabana Akuntansi, 8 (2013), 171-87

Ramlan Ginting Dudy Iskandar, and Gantiah Wuryandani Anggayasti Hayu Anindita Tresna Kholilah, Kodifikasi Peraturan Bank. Indonesia Kelembagaan Penilaian Tingkat Kesehatan Bank Umum (Jakarta: Bank Indonesia, 2013)

Riyadi, Slamet, Banking Assets And Liability Management, Edisi Ke-3 (Jakarta: Lembaga Penerbit Fakultas Ekonomi Universitas Indonesia, 2006)

Rozalinda, Ekonomi Islam Teori Dan Aplikasinya Pada Aktifitas Ekonomi (Jakarta: PT RajaGrafindo Persada, 2015)

Sekaran, Uma, and Roger Bougie, Research Methods for Business: A Skill Building Approach (John Wiley \& Sons, 2016)

Sri Muliawati, Moh. Khoiruddin, 'FaktorFaktor Penentu Profitabilitas Bank Syariah Di Indonesia', Management Analysis Journal, 4 (2015), 39-49

Sufian, Fadzlan, 'Factors Influencing Bank Profitability in a Developing Economy: Empirical Evidence from Malaysia', Global Business Review, 10 (2009)

Suseno, and Siti Astiyah, Seri Kebanksentralan
No. 22 - Inflasi, Bank Indonesia (Jakarta: PPSK Bank Indonesia, 2015)

Widarjono, Agus, Ekonometrika Dan Aplikasinya, Edisi Ke-3 (Yogyakarta: Ekonisia, 2009) 